\title{
Perspectives
}

\section{“The Eyes of Hito": A Japanese Cultural Monitor of Behavior in the Communicative Language Classroom}

\section{David L. Greer}

Tosa Women's Junior College

This paper suggests that Japanese students' sensitivity to bito (person, people, group), or the third-person "other," can result in a disengaged student in the EFL classroom, one who resists communicative language approaches. It explains how bito is enculturated in the Japanese self and monitors the self's behavior and suggests ways that the foreign EFL teacher, aware of bito's influence on the student, can conduct classes with sensitivity to the cultural issues described in this paper.

日本人学習者には「人の目を意識する」という文化的な要因があり、それがコミュニカ ティブなアプローチに抵抗を感じさせると著者は論じる。著者は、「人意識」という現象 がどのようにして日本人の「自己」の一部となるか、そして「人」が日本人の「自己」に どんな影響を及ほすすかということを説明する。終りに、著者は「日本人の「自己】に対す る「人』」の影響を理解している外国人教師のために適当な教授法を推鹰する。

A part of the counseling aspect of Community Language Learning 1 class. These writings serve as the basis for group discussions about issues that the students are most concerned with. Over the years of using CLL I have noticed that an undercurrent flows within these papers, a theme that echoes the "certain restraints and inhibitions" that Miller (1995) has suggested are a result of his English as a foreign language (EFL) students' "social upbringing and prior English study experiences" (p. 46).

The theme at first seemed diffuse. Some students noted their reluctance to initiate a conversation in English because "(another student) might not understand me and that would cause her trouble." Many remarked that they were reluctant to express opinions because they were concerned with, "how the other (students) would feel" should they believe differently. Some worried that the conversation "might 
stop because (they) could not speak English well." Others were loath to begin a conversation because their topic might be "insignificant." Many were afraid that their pronunciation might "sound funny." Some were concerned with speaking in English after "the other students stayed in Japanese." Still more expressed the "fear of making a mistake."

When I read the following comment, written by a second-year women's junior college student in her second year of CLL (approximately the fortieth week of a sixteen-month period), these threads wove themselves into a recognizable pattern. My translation (see Appendix 1 for the student's Japanese original) contains Romanized words and expressions and "literal" English translations to support my interpretation.

When speaking in front of other people (bitomae de) I deliberately pronounced English with a Japanese accent and made a lot of grammatical errors. I didn't want to be thought of (by people), "Who does she think she is" (Kakko tsuketen ja ne yo)? I'm really sensitive about what others think of me (yappari, mawari no me wa kowai; lit., the eyes around me are frightening). Today, when I was trying to pronounce the sentence, "After I graduate. . ." I got flustered; I was relieved when you said, "Don't worry about whether people (in your group) are angry because you can't get the pronunciation down right; every time you and I repeat it, it's good listening practice for them." After hearing that, I thought, boy, next time I'm in the conversation corner I'm going to express myself even more. You can learn English vocabulary and grammar by studying alone; but to overcome what other people think of you (bito no me no kokufuku; lit., to conquer the eyes of hito), and to stop feeling embarrassed and stuff about speaking in English, there isn't a better place to practice than the conversation corner.

The phrase, hitomae de (in front of other people) could have been omitted, as "when speaking" implies an audience. However "the others" implied by hitomae de are not superfluous to the student; she refers to these "others" elsewhere in her paper (mawari no me, hito no me) as the source of her anxiety.

The student even speculated in Japanese about what one of the "others" would say if she used fluent English, "Who does she think she is?" (Kakko tsuketen ja ne yo) or more literally "(You) should not appear to be what you are not." The "literal" translation does not convey the import of the student's choice of language. First speaking the local dialect when quoting the "other," she shifted to a slang variety that has a menacing undertone in the Tokyo dialect, which her native Kochi "country" people regard as socially superior.

But who is this bito, the other that the student is so sensitive to? 


\section{Hito: the Personification of an Aspect of Japanese Culture}

Geertz (1973) wrote, "Becoming human is becoming individual, and we become individual under the guidance of cultural patterns, historically created systems of meaning in terms of which we give form, order, point, and direction to our lives" (p. 52). Hito, the Japanese word for person, is the personification of certain historically-created Japanese systems of meaning that guide the Japanese social self in the direction that Japanese culture has deemed meaningful.

Lebra (1976) wrote that the Japanese are preoccupied with "'social' objects, namely, other human beings, hito in Japanese" (p. 2). She described the Japanese self as "consist(ing) of continuous reflexivity between performance by self and sanctions by the audience" (Lebra, 1992, p. 106), and noted that the number of Japanese words that describe seken $^{2}$ (society, i.e., the collective hito), and the physical attributes that the culture has given bito, "contributes to the sense of immediacy and inescapability of the seken's presence" (Lebra, 1992, p. 107).

Lebra did not imply that bito is unique; bito functions the same way that the ambiguous, third-person "other" does in North American cultures (Johnstone, 1996; Rothstein, 1993). Hito, however, has a greater degree of influence on the Japanese self than the other has on the North American self. Why? Because the historically created systems of meaning in Japan's "tight culture" differ from those in North America's "loose culture" (Triandis, 1985, p. 23). As Markus and Kitayama (1994, p. 102) explained,

the goal (of Japanese enculturation) is not individual awareness, experience, and expression, but rather some attunement or alignment of one's reactions and actions with those of another, and intersubjective experience is a result of these efforts and, in turn, fosters these efforts.

This intersubjective ${ }^{3}$ experience "cultivates a sense of self . . a a a group member and as a person in society" who places the needs of the group over those of the individual (Tobin, 1991, p. 18; cf. Tobin, 1992, p. 35). This is a goal that the North American self, having developed in a "culturally fostered autonomy" (Roland, 1988, p. 100), may find difficult to accept. Kotloff (1996, pp. 98-99), for example, in her study of a Japanese preschool, wrote that the emphasis of the group over the individual "conflicted with my instincts as an American and as a former teacher." She concluded her article, however, with the understanding that this emphasis nurtures individuality to accomplish group goals. ${ }^{4}$

Sato (1996) posed a question that is germane here: "Can group orientation ${ }^{5}$ and individualism be distinguished, as they are in Western thought?" (p. 119). No, they cannot, because the Japanese concepts of "group and 
individual are not dialectically opposed, as in American thought" (Rohlen \& LeTendre, 1996b, p. 76). This is a point that Kondo (1990) amplified:

The (Japanese) self is fundamentally interrelated with others and to understand the Japanese sense of self requires dissolving the self/other or self/society boundary that is such an obvious starting point in all Western formulations of the self ${ }^{6}$ (cited in Markus \& Kitayama, 1994, p. 97).

So what does this have to do with the student who pretended that she could not speak English well? This student suppressed her ability to speak English like a native speaker, placing the needs of her fellow students, the group, over her desire to speak English naturally. Why? Because to cause the others to think that she was "better" at English than they were would violate the intersubjective experience that self has with the other. This is the Japanese notion of empathy. "In America, empathy is shown by giving Alter (i.e., the other) freedom to make up his mind, while Japanese empathy refers to anticipating and taking care of Alter's wants" (Lebra, 1976, p. 40). Alter, the other for this student, does not want her to speak English well.

\section{A Caveat}

This student's short paragraph is only one comment, and my interpretations and supporting evidence reflect only one person's perception. However, as Barnlund (1975) suggests, "the issue . . is not whether cultural generalizations account for every act of every person, but whether they help to explain the meaning of many or most social events" (p. ix).

The student's comments reflect social events, perceptions, and issues that are remarkably similar to those noted by other writers (Asano, 1995; McVeigh, 1997; Nishijima, 1995; Nozaki, 1993; Okada, 1996; Otani, 1995; Ryan, 1995; Sasaki, 1996; Torikai, 1996; Toyota, 1995). Furthermore, if these comments are an anomaly, it is difficult to reconcile the similarities between them and remarks that a young Japanese television personality made during a program about English language learning:

Pronouncing English like a native English speaker is kind of embarrassing; you are laughed at by people around you (mawari no bito nimo warawareru). But, gosh, if you worry about things like that, you're never going to get good at English. What I want to say is, let's stop teasing people who are trying to sound like native English speakers ${ }^{7}$ (Torikai, 1996, p. 5).

Another similarity between the case represented here and the television personality's comment can be found in the original Japanese. In 
both comments two passive clauses (italicized in the student's comments and in the above quote) place the other as the agent ("I didn't want to be thought [odd] by people") and "you are laughed at by people around you." Researchers have suggested that Japanese often use passive clauses to indicate that they have suffered from the action of another (Kuwayama, 1992; Lebra, 1976; Takenaga, 1991). Here, the audience around the self, bito, has threatened to ridicule the self's attempts at natural pronunciation.

\section{Enculturation of Hito}

Understanding the way bito is enculturated in the Japanese self can help prevent the foreign teacher from unwittingly creating the "schism" that Kemp (1995) described as, "a cleavage between students' half-intuited English class expectations and a new and baffling foreign teacherimposed reality totally unrelated to any of their past experience" (p. 11).

The Japanese mother uses bito to strengthen the mother-child relationship (Lebra, 1976; Markus \& Kitayama, 1994). Anderson (1993) referred to it as the "unidentified, seemingly ubiquitous 'someone'"(p. 104) that Japanese mothers call on to discipline their children. The Japanese mother praises her child for good behavior; she disciplines, however, through bito. Hito may be invisible to the child, as in "You are laughable." Hito, however, may be tangible: The "bad" child may be subject to "teasing, ridicule, and embarrassment (emphasis added) ... . laughed at or ridiculed by (those) whose opinion the child values most" (Lebra, 1976, p. 152). Consequently, the Japanese child regards bito ominously: "the third party plays an indispensable role in inducing shame among Japanese" (Lebra, 1976, p. 221).

Hito becomes the "constant . . group context" in which the Japanese self defines itself (Rohlen \& LeTendre, 1996a, p. 10). The infant's awareness of bito is strengthened in a succession of group contexts. ${ }^{8}$ Kotloff's (1996) study, for example, shows how children are taught to find satisfaction in group effort. Tsuchida and Lewis (1996) discuss how this proclivity is encouraged in primary school. First-graders are taught "that there is often a single right way of doing things" in their school activities (p. 195).

Sato (1996) and Fukuzawa (1996) have discussed how teachers use the other to discipline students. Lewis (1996) also noted how the other is invoked to "mask the conflict between the desires of child and teacher" in a Japanese elementary school:

Discipline appealed to feelings. Teachers made comments such as "If you break that hat, your mother will cry," "Your pencil-san will feel 
miserable if you peel it," "Your pianica (piano-harmonica) is crying" (to a girl about to drop her pianica), and "Please behave properly on Parents' Day. If you don't, the parents won't laugh at you, they'll laugh at me (italics added)" (p. 90).

Sato (1996) has suggested that primary school students' actions are constantly monitored by the group: "Going to school means togetherness, for better and for worse" (p. 138). This togetherness is further developed through banse $i^{9}$ group reflection sessions (and/or essays) in which students learn that, "just as there is a 'correct' lifestyle, so there are 'correct' emotions ${ }^{10}$ for particular events" (Fukuzawa, 1996, p. 308). Peak (1991) described hansei in these words,

Once a task has been executed, evaluation, or hansei, is a typical ritualized final step in the process. Group activities, ranging from daily cleaning of the classroom to the yearly class trip, end with a formal student-led period of bansei. Remedial pedagogy and discipline both focus on trying to get the student to reflect on and understand his or her inappropriate behavior and to develop an independent ability for self-evaluation (p. 107).

Where does this "pedagogy and discipline" come from? What is this "inappropriate behavior?" Sato (1996) stressed that student "peer supervision and self-supervision form an integral part of authority and control mechanisms at work in Japanese schools" (p. 138). The students, however, do not spontaneously create these notions; they are culturally transmitted:

banse $i$ was therefore a powerful mechanism of control as well; teachers had the power to observe and respond to the students' reflections and to make the students rewrite or rethink their responses. Undoubtedly, students felt pressure not only to be honest in their reflections but also to conform to adult expectations (Sato, 1996, p. 132).

Hanse $i$ is the vital element in what Rohlen (1996) called "spiritual training" (seishin kyoiku) (p. 50). This training encourages students to adhere to "teachers' examples and group standards" and discourages "nonconformity (which) is viewed as disruptive of group unity and a sign of character weakness" (Rohlen, 1996, p. 73).

\section{Applying This Information to EFL Classrooms}

Behavior that disrupts group unity may result in the schism that Kemp (1995) described. When a teacher asks a student to perform in a way that risks group disapproval, the student may resort to avoidance strategies similar to the "unresponsiveness" and "lack of spontaneity" that 
Nozaki (1993, p. 28) reported and, if pressed, refuse to participate (as Lebra, 1976, explained in a different context).

Thus, the best way to avoid disrupting group unity is to design activities that involve the entire class in a group context. Akita (1995, p. 51) wrote that "Japanese may act extremely shy individually, but in a group they can act extrovertly." Miller (1995, p. 43), for example, realizing that asking open questions to the class did not elicit spontaneous responses, singled out students to answer. The students balked initially, but soon acknowledged, as one student wrote, "it becomes a group thing, so that's fine" (p. 44).

Izumi (1995, p. 10) had her students debate successfully by having groups of students present and defend their arguments, thus "better accommodat[ing the debate format to] Japanese people's cultural behavior." Miller (1995) also required his students to make short "extemporaneous" speeches but allowed them to prepare the speeches in advance. Although not truly spontaneous, the speeches were successful in that the students practiced a difficult activity through a "procedure (that) seemed well-suited to Japanese sensibilities" (p. 44).

Of course, students tend to be more receptive when they know in advance what their teacher expects of them. For example on the first day of his course, Tomei (1996) distributed a detailed handout that explained the aims of the course, his policy on grading, homework, and absences, and included a list of supplementary material. He notes that a colleague made a similar handout into a quiz that the students had to pass with a perfect score before they could join the class.

Thus, it is advisable to give students the course syllabus on the first day of class and copies of the lesson plan at the beginning of each class, including the time frame for all activities. When students see what is expected of them, it is likely that they will fall into a rhythm, their anxiety will decrease, and they will become more motivated. For example, Hunter (1995, p. 5) succeeded in having his students ad lib situations because he knew that "repetition of a task can contribute to the lowering of inhibitions, the encouragement of risk-taking, and the building of self-confidence."

Izumi (1995) suggests that "the fear of being laughed at by peers because of mistakes or the use of unrefined English may make students shy" (p. 10). Throughout this paper, passages from student comments indicate how ridicule inhibits self-expression. The first student wanted "to stop feeling embarrassed" when she spoke in English and was leery of ridicule. The television personality warned that natural English pronunciation provokes laughter from those around the speaker, supporting Lebra's contention that children may be subject to "teasing, ridicule, 
and embarrassment. . . . laughed at or ridiculed by (those) whose opinion the child values most" (Lebra, 1976, p. 152). The teacher used the threat of laughter to discipline a grade-school student (Lewis, 1996, p. 90). Finally, Markus and Kitayama's (1994) present the following example: "Kazuo, you are acting very strange; your friends may laugh at you if they see it" (p.115).

The issue of laughter is very complicated and requires further research. What, for example, causes students to laugh in a particular teacher's classroom? What is the reaction of the students who are the object of laughter? Is the laughter meant to be derisive? Or is the laughter meant to be empathetic, to release tension? Is the activity the source of the tension? If so, how could the activity be modified to reduce the amount of tension? Questions like these indicate the complexity of the issue. They also indicate, however, the need for teachers to be aware. Listen to the laughter in your classroom, determine its type and source, and find a way to avoid negative sources in the future.

\section{Conclusion}

Human emotions are essentially universal (Erchak, 1992; Geertz, 1973; Lebra, 1992). Nonetheless, we must acknowledge that "each culture's values about emotions and their expression may come to affect the essential experience (and the expression and, ultimately, the definition) of that emotion" (Ellsworth, 1994, p. 40). From this perspective we can understand that the Japanese bito may, indeed, be generally similar to the Western "other." However, we can also understand that the essential experience that the Japanese self has with bito is much closer than the essential experience that the Western self has with the monitor of its behavior.

Culture consists of symbols, like the word bito, and the readiness with which we accept these symbols, and the emotions that they elicit in our students, depends on how familiar we are with the symbols and the emotions that the symbols evoke.

\section{Acknowledgments}

Thanks are due to the reviewers, who I hope will see in this revised version my gratitude for their conscientiousness in reviewing the original article.

David Greer, a lecturer at Tosa Women's Junior College, has taught English in Japan since 1982. 


\section{Notes}

1. CLL is an approach to language learning in which the bilingual teacher uses counseling techniques to alleviate the anxiety students feel toward speaking in foreign languages (Curran, 1972). The connection of CLL with the argument in this paper is that the approach places students in situations in which the effects of bito are more apparent than in approaches that are designed to compensate for bito's influence; consequently, student reports that deal with bito are common. The "conversation corner" that the student refers to in her report is a CLL activity.

2. Lebra (1992) listed more synonyms of seken, and their English equivalents, with the caveat that the English words "do not fully convey the (Japanese) self's sensitivity to interactional immediacy and vulnerability entailed in the Japanese terms" (p. 106). Kuwayama (1992) listed three levels of the "other": mawari (people around), bito (people at large), and seken, (society). The three levels are concentrically related to the self (jibun) at the center (p. 122).

3. For the differences between independent and interdependent notions of self, see Kim and Sharkey (1995); for child-raising practices that inculcate these differences, see Barnlund (1975), Erchak (1992), Lebra (1976), Markus and Kitayama (1994), Morsbach (1980), and Rosenberger (1992).

4. Kotloff's article explains how the interdependent Japanese culture pays more attention to the emotional needs of its members as individuals than do cultures that stress individualistic ideals, a point that Frijda and Mesquita (1994) have also made (see also Sato, 1996).

5. Sato's (1996) conception of Japanese social behavior as "relations oriented" (p. 119) correlates with Lebra's notion of social preoccupation. To distance her concept (and, by extension, Lebra's) from group-oriented stereotypes, Sato noted that these social relations may be a single person, one's selfimage, or the social environment. Compare this with Lebra (1976): "Japanese individuality... rests not on the imposition of one's will on the social environment but on the refusal to impose oneself on it" (p. 43). Similarly, Singleton (1991) wrote that Japanese culture inculcates, "the messages of shudan ishiki (group consciousness). Exclusive group solidarity and commitment are part of the real (or hidden) curriculum of the educational process" (pp. 122-123). Singleton further explained, however, that the emphasis on group consciousness does not suppress the Japanese sense of the individual.

6. Compare this with Smith (1983): "the identification of self and other is always indeterminate in the sense that there is no fixed center from which...the (Japanese) individual asserts a noncontingent existence" (p. 81). Also see the essays in Bachnik and Quinn (1994).

7. Torikai (1996) noted that the television personality was in her early twenties and remarked on her youth and her sensitivity to bito's ridicule: "kore wa masashiku, jidai wo koeta 'Nibonjinrashisa' to ieru" (this is a clear example of "Japaneseness" that transcends generations; my translation) (p. 6). Compare this with Nozaki (1993): "Beneath a deceptively Westernized veneer, 
(Japanese students') core values remain traditionally Japanese" (p. 27).

8. Markus and Kitayama (1994) wrote that Japanese parents believe the preschool's "duty (is) to teach group living" (p. 115; a similar suggestion is found in Rohlen \& LeTendre, 1996a, p. 6). Tobin (1991) noted that the preschool child learns to, "cultivate a sense of self . . . as a group member and as a person in society" (p. 18; also see Tobin, 1992, p. 35, and Rosenberger, 1992: "The crafting of selves embedded in reciprocal relationship" [p. 13].). Finkelstein (1991) wrote that preschool education does not rob children of their individuality; rather it, "help(s) them acquire a more group-oriented, outward-facing sense of self than they received in the first three years of life" (p. 78; also see Kotloff, 1996, p. 111). Lewis (1991) explained this, "as orientation to seek mutual benefit rather than individual benefit when the two conflict" (p. 82). Peak (1991) wrote that Japanese preschool education is, "foreign to American cultural beliefs about appropriate educational goals" (p. 98). However Kotloff (1996) noted that these are "collective goals (that) are central to life in Japan-the desire to work for the sake of the group and the capacity to gain satisfaction from doing so" (p. 99). Thus, in the Japanese preschool, "with (its) large (teacherstudent) ratios and large classes ... children are most likely to get the chance to interact intensively with other children and to learn shakaisei (social consciousness) and shudan seikatsu (group life)" (Tobin, Wu, \& Davidson, 1991, p. 115; also see Tobin 1992, pp. 25, 31).

9. Fukuzawa (1996) noted that hansei "may be translated as 'reflection,' but (the Japanese word hanse $i$ ) has overtones of self-criticism and confession measured against the yardstick of socially defined norms of behavior and emotions" (p. 308).

10. Fukuzawa (1996) acknowledges the contributions of Catherine Lewis (1991; 1996) to the notion of "correct" emotions.

\section{References}

Akita, K. (1995). Japanese-culture-enhanced English class. The Language Teacher, 19 (5), 51-52.

Anderson, F. (1993). The enigma of the college classroom: Nails that don't stick up. In P. Wadden (Ed.), A bandbook for teaching English at Japanese colleges and universities (pp. 101-110). Oxford: Oxford University Press.

Asano, H. (1995 May). Nigate ishiki wa itsu, doshite umareru ka [When, and from where, do we get the feeling we can't speak English?]. Eigo Kyoiku: The English Teacher's Magazine, 44 (3) 17-19.

Bachnik, J., \& Quinn, C. (Eds.). (1994). Situated meaning: Inside and outside in Japanese self, society, and language. Princeton: Princeton University Press.

Barnlund, D. (1975). Public and private self in Japan and the United States: Communicative styles of two cultures. Yarmouth, ME: Intercultural Press.

Curran, C. (1972). Counseling-learning: A whole-person model for education. Apple River, IL: Apple River Press.

Ellsworth, P. (1994). Sense, culture, and sensibility. In S. Kitayama \& H. Markus (Eds.), Emotion and culture: Empirical studies of mutual influence (pp. 23- 
50). Washington, DC: American Psychological Association.

Erchak, G. (1992). The anthropology of self and behavior. New Brunswick, NJ: Rutgers University Press.

Finkelstein, B. (1991). Introduction: Culture and schooling in Japan. In B. Finkelstein, A. Imamura, \& J. Tobin (Eds.), Transcending stereotypes: Discovering Japanese culture and education (pp. 77-80). Yarmouth, ME: Intercultural Press.

Frijda, N., \& Mesquita, B. (1994). The social roles and functions of emotions. In S. Kitayama \& H. Markus (Eds.). Emotion and culture: Empirical studies of mutual influence (pp. 51-87). Washington, DC: American Psychological Association.

Fukuzawa, R. (1996). The path to adulthood according to Japanese middle schools. In T. Rohlen \& G. LeTendre (Eds.), Teaching and learning in Japan (pp. 295320). Cambridge: Cambridge University Press.

Geertz, C. (1973). The interpretation of cultures. New York: Basic Books.

Hunter, L. (1995). Ad-libbing as a language learning objective. The Language Teacher, 19 (1) 4-7.

Izumi, K. (1995). Teaching debate in Japanese high schools. The Language Teacher, 19 (7) 9-11.

Johnstone, B. (1996). The linguistic individual: Self-expression in language and linguistics. Oxford: Oxford University Press.

Kemp, J. (1995). Culture clash and teacher awareness. The Language Teacher, 19 (8), 8-11.

Kim, M., \& Sharkey, W. (1995). Independent and interdependent construals of self: Explaining cultural patterns of interpersonal communication in multi-cultural organizational settings. Communication Quarterly, 43 (1) 20-38.

Kondo, D. (1990). Crafting selves: Power, gender, and discourses of identity in a Japanese work place. Chicago: University of Chicago Press.

Kotloff, L. (1996). "...And Tomoko wrote this song for us.” In T. Rohlen \& G. LeTendre (Eds.), Teaching and learning in Japan (pp. 98-118). Cambridge: Cambridge University Press.

Kuwayama, T. (1992). The reference other orientation. In N. Rosenberger, (Ed.), Japanese sense of self (pp. 121-151). Cambridge: Cambridge University Press.

Lebra, T. (1976). Japanese patterns of behavior. Honolulu: University of Hawaii Press.

Lebra, T. (1992). Self in Japanese culture. In N. Rosenberger, (Ed.), Japanese sense of self (pp. 105-120). Cambridge: Cambridge University Press.

Lewis, C. (1991). Nursery Schools: The transition from home to school. In B. Finkelstein, A. Imamura \& J. Tobin (Eds.), Transcending stereotypes: Discovering Japanese culture and education (pp. 81-95). Yarmouth, ME: Intercultural Press.

Lewis, C. (1996). Fostering social and intellectual development: The roots of Japan's educational success. In T. Rohlen \& G. LeTendre (Eds.), Teaching and learning in Japan (pp. 79-97). Cambridge: Cambridge University Press.

Markus, H., \& Kitayama, S. (1994). The cultural construction of self and emotion: Implications for social behavior. In S. Kitayama \& H. Markus (Eds.), Emo- 
tion and culture: Empirical studies of mutual influence (pp. 89-130). Washington, DC: American Psychological Association.

McVeigh, B. (1997). Life in a Japanese women's college: Learning to be ladylike. London: Routledge.

Miller, T. (1995). Japanese learners' reactions to communicative English lessons. JALT Journal, 17 (1), 31-52.

Morsbach, H. (1980). Major psychological factors influencing Japanese interpersonal relations. In N. Warren (Ed.), Studies in cross-cultural psychology Vol. 2 (pp. 317-344). New York: Academic Press.

Nishijima, H. (1995 May). Nibonjin Eigo no jakuten wa nani ka [Problems Japanese speakers have with English]. Eigo Kyoiku: The English Teacher's Magazine, 44 (3), 14-16.

Nozaki, K. (1993). The Japanese student and the foreign teacher. In P. Wadden (Ed.), A bandbook for teaching English at Japanese colleges and universities (pp. 27-33). Oxford: Oxford University Press.

Okada, J. (1996). Kokosei no konomu gakushu stairu to sono kojinsa no patan (Individual patterns in high school students' preferred learning styles). STEP Bulletin, 8, 110-119.

Otani, Y. (1995). Nibonjin no mentariti to igengogakushu [The Japanese mentality and foreign language learning]. Eigo Kyoiku: The English Teacher's Magazine, 44 (3), 8-10.

Peak, L. (1991). Training learning skills and attitudes in Japanese early education settings. In A. Imamura \& J. Tobin (Eds.), Transcending stereotypes: Discovering Japanese culture and education (pp. 96-108). Yarmouth, ME: Intercultural Press.

Rohlen, T. (1996). Building character. In T. Rohlen \& G. LeTendre (Eds.), Teaching and learning in Japan (pp. 50-74). Cambridge: Cambridge University Press.

Rohlen, T., \& LeTendre, G. (Eds.). (1996a). Introduction: Japanese theories of learning. Teaching and learning in Japan (pp. 1-15). Cambridge: Cambridge University Press.

Rohlen, T., \& LeTendre, G. (Eds.). (1996b). Section II: The emotional foundations of early learning. Teaching and learning in Japan (pp. 75-78). Cambridge: Cambridge University Press.

Roland, A. (1988). In search of self in India and Japan: Toward a cross-cultural psychology. Princeton: Princeton University Press.

Rosenberger, N. (Ed.). (1992). Introduction. Japanese sense of self (pp. 1-20). Cambridge: Cambridge University Press.

Rothstein, S. (1993). The voice of the other: Language as an illusion in the formation of the self. Westport, CT: Praeger.

Ryan, S. (1995). Misbehavior in the university classroom? A cross-cultural survey of students' perceptions and expectations. The Language Teacher, 19 (11), 13-16.

Sasaki, C. (1996). Teacher preferences of student behavior in Japan. JALT Journal, 18 (2), 229-239.

Sato, N. (1996). Honoring the individual. In T. Rohlen \& G. LeTendre (Eds.), Teaching and learning in Japan (pp. 119-153). Cambridge: Cambridge Uni- 
versity Press.

Singleton, J. (1991). The spirit of gambaru. In B. Finkelstein, A. Imamura, \& J. Tobin (Eds.), Transcending stereotypes: Discovering Japanese culture and education (pp. 119-125). Yarmouth, ME: Intercultural Press.

Smith, R. (1983). Japanese society: Tradition, self, and the social order. Cambridge: Cambridge University Press.

Takenaga, Y. (1991). Kikoku seito no gengokyoiku [Teaching Japanese to Japanese students returning from abroad]. Tokyo: Sanseido.

Tobin, J. (1991). Front and rear (omote and ura). In B. Finkelstein, A. Imamura \& J. Tobin (Eds.), Transcending stereotypes: Discovering Japanese culture and education (pp. 17-19). Yarmouth, ME: Intercultural Press.

Tobin, J. (1992). Japanese preschools and the pedagogy of selfhood. In N. Rosenberger (Ed.), Japanese sense of self (pp. 21-39). Cambridge: Cambridge University Press.

Tobin, J., Wu, D., \& Davidson, D. (1991). Forming groups. In B. Finkelstein, A. Imamura, \& J. Tobin (Eds.), Transcending stereotypes: Discovering Japanese culture and education (pp. 109-117). Yarmouth, ME: Intercultural Press.

Tomei, J. (1996). Classroom management in the Japanese classroom. The Language Teacher, 20 (6) 19-21.

Torikai, K. (1996). Ibunka wo koeru Eigo: Nibonjin wa naze hanasenai ka [English, the language that transcends culture: Why can't the Japanese speak it?]. Tokyo: Maruzen.

Toyota, M. (1995 May). "Wakariau bunka" wa gaikokugoshutoku no shogai ka? [Is the "culture of tacit understanding" an obstacle to the acquisition of foreign languages?] Eigo Kyoiku: The English Teacher's Magazine, 44 (3), 11-13.

Triandis, H. (1985). Some major dimensions of cultural variation in client populations. In P. Pederson (Ed.), Handbook of cross-cultural counseling and therapy (pp. 21-28). Westport, CT: Praeger.

Tsuchida, I., \& Lewis, C. (1996). Responsibility and learning: Some preliminary hypotheses about Japanese elementary classrooms. In T. Rohlen \& G. LeTendre (Eds.), Teaching and learning in Japan (pp. 190-212). Cambridge: Cambridge University Press. 